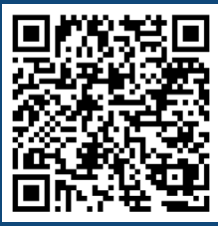

Keywords:

Afforestation

Climate change

Geographical distribution

Bioclimatic variables

Habitat suitability

Maxent

Species distribution models

Received 16/05/2019

Accepted 27/I I/2019

Correspondence: ayhanakyol@isparta.edu.tr
Ayhan Akyol ${ }^{\text {la+ }}$, Ömer Kamil Örücü2a

\section{INVESTIGATION AND EVALUATION OF STONE PINE (Pinus pinea L.) CURRENT AND FUTURE POTENTIAL DISTRIBUTION UNDER CLIMATE CHANGE IN TURKEY}

AKYOL, A.; ORUCU, O. K. Investigation and evaluation of stone pine (Pinus pinea L.) current and future potential distribution under climate change in Turkey. CERNE, v. 25, n. 4, p. $415-423,2019$.

\section{HIGHLIGHTS}

The most effective bioclimatic variable in the potential distribution of stone pine was minimum temperature of coldest month (Bio6).

The prediction model in 2050-2070 and RCP4.5-8.5 showed that the stone pine habitat would decrease.

According to prediction model, stone pine will shift geographical distribution towards north sites.

The most suitable potential habitats should be prioritized for afforestation investments.

\section{ABSTRACT}

Climate change has negative effects on especially plant species that have a limited habitat. In this context, the stone pine (Pinus pinea L.), which has a limited distribution, is prominent with its economic, ecological and aesthetical characteristics, and it is frequently preferred in afforestation. In this study, the habitats in Turkey that are suitable for distribution of $P$. pinea L. were modelled by using Maxent based on high-resolution environmental data. In total, I 3 field-based occurrence points and I 9 bioclimatic variables were used to model the potential distribution area under current and two prediction model (RCP4.5 and RCP8.5) for the years 2050 and 2070. According to the results, the most important bioclimatic variables effective on the potential distribution of $P$. pinea $L$. were found as the minimum temperature of coldest month (Bio6), annual precipitation (Biol2) and precipitation of wettest quarter (Biol6). Prediction models under two future climate change scenarios displayed that $P$. pinea L. will lose habitat and it will shift geographical distribution towards north and higher elevation sites. Considering especially the economic contributions provided by P. pinea L., these results necessitate consideration of the areas where the rate of potential distribution of the species is the highest in afforestation work aiming rural development. In addition to habitat losses, climate change affects many variables of the ecosystem. 


\section{INTRODUCTION}

Turkey is a highly rich country in terms of diversity of plant species (Davis, 1982; Davis et al., 1988), and it contains many plant species which show a natural distribution and commercial importance. The number of people who live especially in rural areas and utilize these plants directly and indirectly is very high, and these species also have great significance in terms of rural development practices. In this context, stone pine (Pinus pinea L.), which is one of the species that are naturally distributed in the Mediterranean forest ecosystem, is frequently preferred and utilized afforestation practices. However, P. pinea L. does not have a broad distribution in the world. Approximately $70 \%$ of the P. pinea L. forests of the world are located in Spain, and most of these forests in Spain are plantations (Bravo-Oviedo and Montero, 2005). The countries where the species naturally grows are Spain, Portugal, Italy, France, Corsica, Turkey, Greece, Lebanon and Syria. In addition to these, it is known that plantations are made in countries like Albania, Croatia, Serbia, Russia, Ukraine, Cyprus, Israel, Libya, Morocco, South Africa, Tunisia, Argentina and Brazil. P. pinea L. locally is distributed in Bergama-Kozak, Aydın-Koçarlı, Muğla, Antalya-Manavgat, Gemlik, ArtvinFıstıklı village, Trabzon-Kalenema, KahramanmaraşHacıağalar and Önsen villages and Bartın-Çakraz and has a high economic value (Yaltırık, 1988; Kılcı et al., 2000; Batur, 20I5; Güleç, 20I5).

In recent years, in addition to socioeconomic studies related to non-wood forest products, ecological studies have increased (Ticktin, 2004). In addition to its good ecological adaptation to high temperatures and drought, $P$. pinea $L$. also tolerates water stresses to a significant extent thanks to its deep roots (Castillo et al., 2002; Teobaldelli et al., 2004). P. pinea L. is also a more durable species in comparison to other pine species in the Mediterranean forest ecosystem against diseases and pests (YIImaz and Erbilgin, 20I0). Stone pine is frequently preferred in afforestation practices due to its ecological, economic and aesthetical characteristics, and it is among the top species that provide important contribution to the national economy as a non-wood product (Kırdar et al., 20I0; Kurt et al., 2016). As it is a highly valuable product in international markets, it provides producers with more income in comparison to other forest products (Mutke et al., 2005). Especially cone and pine nut production has very significant social and economic contributions in forest villagers. This is why $P$. pinea $L$. is planted in Turkey intensively for achieving multifunctional purposes such as pine nut production, production of wood for construction and fuel and recreational uses (Moreno-Fernández et al., 2013; Üçler and Arpacı, 2017). Studies in recent years have demonstrated that it provides successful results in afforestation and rehabilitation of mining sites (Keskin and Makineci, 2009).

Considering exports numbers, it is seen that the income provided by $P$. pinea $L$. is increasing year to year (Şafak and Okan, 2004) and has reached approximately 100 million dollars according to 2018 data (OGM, 20I8). This situation provides information on why public and private sector afforestation practices to be carried out with $P$. pinea $L$. are important and shows that this species will also be preferred intensively in the future in afforestation practices in rural development processes due to economic reasons. Indeed, 33750 hectares (ha) of the $P$. pinea $L$. forests in Turkey with a total area of approximately 92900 ha are natural, while 59150 ha consist of afforestation and plantation (OGM, 2006; Üçler and Arpacı, 2017). Hence, the forestry sector obtains many benefits from $P$. pinea $L$. afforestation in terms of both sustainable forest management and rural development.

While P. pinea $L$. is an economically valuable plant species, its geographical distribution in the future dependent on global warming and climate change is uncertain. It is known that climate plays a determining role in the large-scale distribution of species (Guisan and Thuiller, 2005). Additionally, it is one of the most important factors that affect the growth and reproduction of organisms (Lawler et al., 2009). It is expected that land, freshwater and seawater species will change their geographical distribution, seasonal activities, migration patterns, populations and species interactions in the future due to the ongoing climate change (IPCC, 20I4). Therefore, species distribution models (SDMs) are used to determine the ecological needs of species and estimate their potential distribution ranges in terms of regional ecology and biogeography (Franklin, 20I3). One of the most prevalently used models is the Maximum Entropy Model (Maxent). The Maximum Entropy Model is a method that aims to determine how different environmental variables affect the suitability of the habitat of a species. Maxent is a software that estimates the distribution of species by using the maximum entropy algorithm and occurrence records of species (Phillips et al., 2017). For this purpose, Maxent adopts a grid shape. If a certain grid area is determined as suitable, this means that the area has the most suitable climatic and environmental conditions for the species (Phillips et al., 2006; Zhang et al., 2019). The main reason for common 
usage of Maxent is that it works only with occurrence data. This is because it is highly difficult to determine the gaps in absence data (Phillips and Dudík, 2008). In short, the model output of Maxent shows the predictability of the relative probability of a species' occurrence in an area (Sharma et al., 2018).

Projections about the climate conditions in the future estimate that there will be many substantial changes in the world such as increased average global temperature, reduced precipitation and alterations in annual patterns (Allison et al., 2009; Zank et al., 2014). As a result of this situation, while some species are expected to change their geographical distribution or adapt to new conditions, it is expected that some other species, especially those with limited habitats, will go extinct (Hughes, 2000; McLachlan et al., 2005; Parmesan, 2006; Root and Schneider, 2006; Schivo et al., 2019). Understanding species distributions based on changing environmental processes provides important information on the design of protection strategies for species (Guisan and Thuiller, 2005; Falcucci et al., 2007). While many researchers who are interested in the topic reveal whether or not climate change occurs on local, regional and global levels by using existing data on one hand, on the other hand, they continue to provide models and projections on climate change in future years by interpreting the existing situation (Coumou and Rahmstorf, 2012; Sisco et al., 2017; Şensoy and Ateşoğlu, 2019). Based on this approach, it is aimed to establish a connection between what kind of a distribution of species will show in the future and the course of climate change. By this, it is aimed to support protection and development activities for species that could be affected by climate change.

In this context, the objectives of this study are: (I) determining the most important environmental factors that affect the potential distribution of $P$. pinea $L$., (2) estimating the potential distribution of $P$. pinea $L$. under current and future RCP4.5-RCP8.5 models for the years 2050 and 2070 , (3) providing reference data for planners in terms of usage, protection and development of $P$. pinea $L$. in afforestation activities with the purpose of rural development.

\section{MATERIAL AND METHODS}

\section{Species occurrence and environmental data}

This study used the Maxent model that utilizes the maximum entropy algorithm to estimate the potential distribution of $P$. pinea $L$. under current and projected future bioclimatic conditions. This model requires the occurrence records of the species that are being modelled and data related to environmental and climatic variables for the habitat. To be used for the study as the species presence data, records obtained in the year 2019 from 13 regions where $P$. pinea $L$. is distributed in Turkey were utilized (Figure I) (Table I). For this purpose, geographical coordinates were obtained by using the Geographical Positioning System (GPS) and the relevant literature (Davis, 1982; Davis et al., 1988; GBIF, 2019; EUFORGEN, 2019).

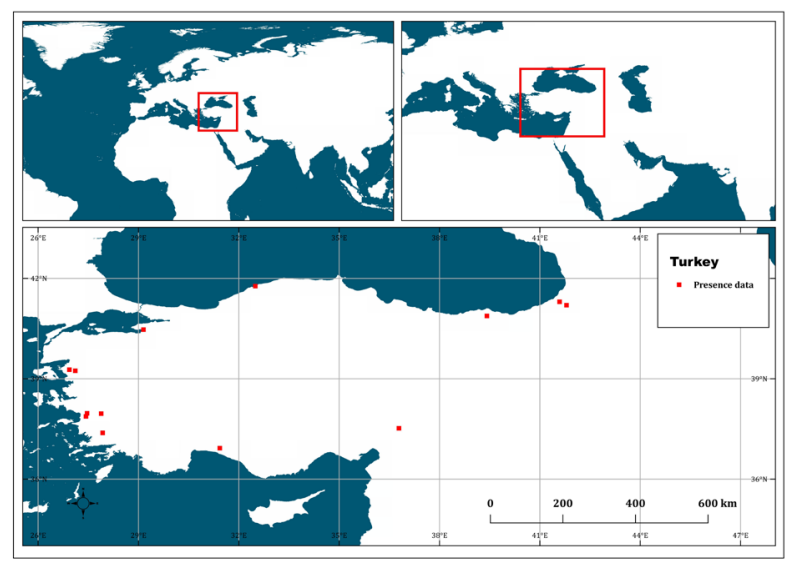

FIGURE I The location of Pinus pinea L. occurrence sites in Turkey.

Bioclimatic variables are values that are derived from monthly temperature and precipitation values to form more meaningful variables, and they are usually used in species distribution modelling and ecological modelling techniques. These variables represent annual trends (e.g., average annual temperature, annual precipitation), seasonality (e.g., annual range of temperature and precipitation) and extreme or restricting environmental factors (e.g., temperature of the coldest and hottest month or precipitation in dry and wet quarters). The bioclimatic variables were obtained for the current situation by WorldClim Version I (1960-1990) and the future by WorldClim Version I.4 (2050 and 2070) (Biol19) (Table 2) from the WorldClim database at a high resolution (Hijmans et al., 2005; WorldClim, 2019). The 2050 bioclimatic data were the average values between $204 \mathrm{I}$ and 2060, and the 2070 bioclimatic data were the average values between $206 \mathrm{I}$ and 2080 .

Modelling methods and statistical analysis

The study used the HadGEM2-ES (Hadley Global Environment Model 2 - Earth System) model as the climate model. HadGEM2-ES is a coupled Earth System Model that is used for centennial simulations. The HadGEM2-ES climate model comprises an atmospheric GCM at N96 and L38 horizontal and vertical resolution, 
TABLE I Geographic coordinates and attribute information of presence data.

\begin{tabular}{|c|c|c|c|c|c|c|c|}
\hline Sample & Province & District & $x$ & $Y$ & $\begin{array}{c}\text { Altitude } \\
(\mathrm{m})\end{array}$ & $\begin{array}{c}\text { Temperature } \\
\left({ }^{\circ} \mathrm{C}\right)\end{array}$ & $\begin{array}{c}\text { Precipitation } \\
(\mathrm{mm})\end{array}$ \\
\hline $\mathrm{I}$ & Balıkesir & Ayvalık & $26.9343 \mid$ & 39.27060 & 298 & 14.42 & 58.25 \\
\hline 2 & İzmir & Bergama & 27.11072 & 39.23884 & 703 & 12.68 & 61.67 \\
\hline 3 & Aydin & Germencik & 27.43111 & $37.8747 \mid$ & 238 & 16.72 & 60.50 \\
\hline 4 & Aydin & Merkez & 27.88460 & 37.95858 & 1113 & 12.08 & 67.08 \\
\hline 5 & Artvin & Borcka & 41.59120 & 41.30053 & 418 & 11.12 & 113.33 \\
\hline 6 & Bursa & Gemlik & 29.14985 & 40.46865 & 378 & 13.43 & 52.50 \\
\hline 7 & Bartın & Kurucaşile & 32.49477 & 41.76757 & 146 & 12.92 & 65.92 \\
\hline 8 & Trabzon & Düzköy & $39.4|87|$ & 40.87739 & 582 & 11.48 & 68.58 \\
\hline 9 & Artvin & Merkez & 41.79814 & 41.19936 & 471 & 11.40 & 89.58 \\
\hline 10 & K. Maras & Merkez & 36.78781 & $37.5|88|$ & 829 & 15.54 & 57.75 \\
\hline 11 & İzmir & Tire & 27.46449 & 37.96760 & 560 & 15.43 & 62.00 \\
\hline 12 & Antalya & Manavgat & 31.43159 & 36.92492 & 261 & 17.43 & 79.67 \\
\hline 13 & Muğla & Yatağan & 27.92916 & 37.38292 & 662 & 15.30 & 67.92 \\
\hline
\end{tabular}

TABLE 2 Bioclimatic variables.

\begin{tabular}{cc}
\hline Codes & Bioclimatic Variables \\
\hline Biol & Annual Mean Temperature \\
Bio2 & Mean Diurnal Range (Mean of monthly (max temp - min temp)) \\
Bio3 & Isothermality (Bio2/Bio7) $(*$ I00) \\
Bio4 & Temperature Seasonality (standard deviation *100) \\
Bio5 & Max Temperature of Warmest Month \\
Bio6 & Min Temperature of Coldest Month \\
Bio7 & Temperature Annual Range (Bio5-Bio6) \\
Bio8 & Mean Temperature of Wettest Quarter \\
Bio9 & Mean Temperature of Driest Quarter \\
Biol0 & Mean Temperature of Warmest Quarter \\
Biol1 & Mean Temperature of Coldest Quarter \\
Biol2 & Annual Precipitation \\
Biol3 & Precipitation of Wettest Month \\
Biol4 & Precipitation of Driest Month \\
Biol5 & Precipitation Seasonality (Coefficient of Variation) \\
Biol6 & Precipitation of Wettest Quarter \\
Biol7 & Precipitation of Driest Quarter \\
Biol8 & Precipitation of Warmest Quarter \\
Biol9 & Precipitation of Coldest Quarter \\
\hline
\end{tabular}

and an ocean GCM with a I-degree horizontal resolution (increasing to I/3 degree at the equator) and 40 vertical levels. The Earth system components are terrestrial and ocean carbon cycle and tropospheric chemistry. Terrestrial vegetation and carbon are represented by the dynamic global vegetation model of TRIFFID which simulates the coverage and carbon balance of 5 types of vegetation (broadleaf tree, needleleaf tree, C3 grass, C4 grass and shrub) (ENES, 2019).

The modelling process utilized the climate change scenarios reported in the Fifth Assessment Report of the United Nations Intergovernmental Panel on Climate Change (IPCC5) Representative Concentration Pathways (RCP) RCP 4.5 and RCP 8.5. RCPs are used in climate modelling processes and research with the purpose of defining the climate scenarios that are considered to be possible based on the greenhouse gas emission amounts in the near future (Moss et al., 2008).

This study used Maxent 3.4.I that uses the maximum entropy algorithm to estimate the potential distribution of $P$. pinea $L$. in Turkey under the current and future bioclimatic conditions (Elith, et al., 20ll). The performance of a Maxent model may be tested by Receiver Operating Characteristic (ROC) analyses (Fielding and
Bell, 1997). The Area Under ROC Curve (AUC) value that is obtained may be interpreted as the estimated probability of the presence of a randomly selected grid cell in a model. AUC defines the success of the model with all possible thresholds. If this value is AUC> 0.5, the model is shown to have a better performance than a random estimation (Phillips, 20I0). The closer the AUC value is to $\mathrm{I}$, the better the distinction is, and the more sensitive and descriptive is the model (Phillips et al., 2006; Oliveira et al., 2010). AUC $\geq 0.9=$ very good, $0.9>A \cup C \geq 0.8=$ good and $A U C<0.8=$ weak (Gassó et al., 20I2). In order to determine environmental variables, the Jackknife option which allows measurement of the effects of environmental variables was selected in the Maxent modelling program (Sarıkaya et al., 2018). This option allows determination of the significance of the effect of each independent variable in forming the model. The values 0 and I were used while creating the potential distribution maps, and accordingly, while I showed the most suitable area where the species may be found, 0 meant that the presence of the species in that area was impossible (0-0.5 unsuitable habitat, 0.5-0.75 suitable habitat, 0.75-I highly suitable habitat). Modelling was restricted to the area covered by the northern latitudes of $35^{\circ}-43^{\circ}$ and eastern longitudes of $26^{\circ}-46^{\circ}$ considering the geographical borders of Turkey.

\section{RESULTS}

Model performance and contribution of environmental variables

According to the model, due to the AUC>0.5, the model performed better than a random estimate. The obtained 0.925 AUC value proved the sensitivity of the model (Figure 2). These results showed that the performance of the model was very good, that is, the model had a high power of estimation.

Jackknife is an option that allows measurement of the effects of environmental variables in the Maxent modelling software. Accordingly, the Jackknife option 


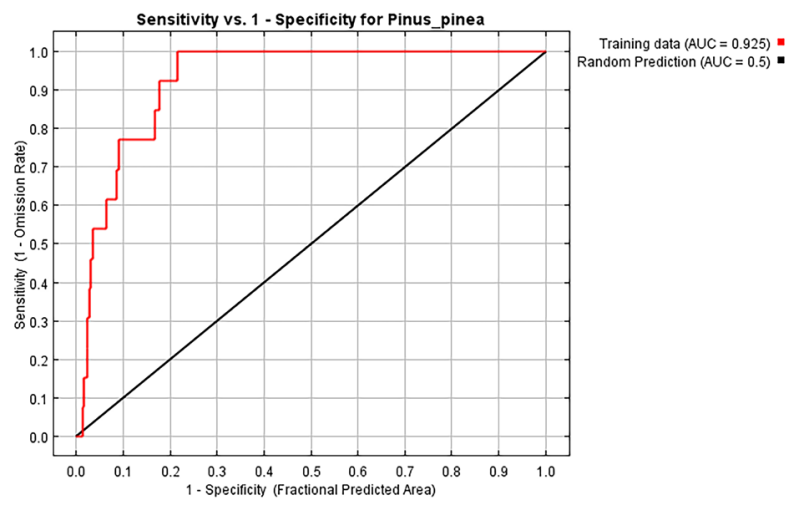

FIGURE 2 AUC values of the MaxEnt model

was selected for P. pinea L., and a Jackknife of regularized training gain created (Figure 3 ). Three environmental variables that affected the species' distribution the most by themselves could be listed in order from the most to the least effective were the minimum temperature of coldest month (Bio6), annual precipitation (Biol2) and precipitation of wettest quarter (Biol6). That is, Bio6, Biol2 and Biol 6 were the most significant bioclimatic variables for prediction of the current potential distribution of $P$. pinea $\mathrm{L}$.

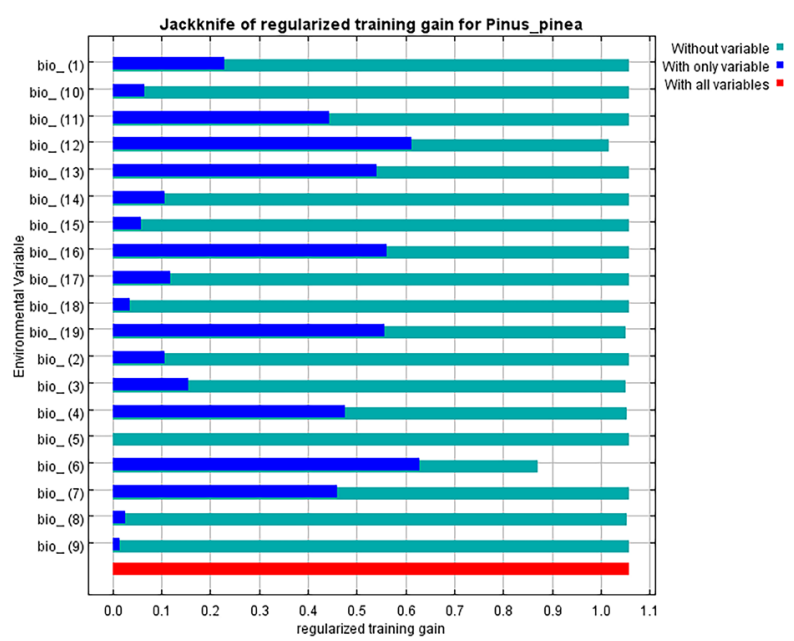

FIGURE 3 Jackknife test for relative importance of bioclimatic variables

\section{Predicted current and future potential $P$. pinea L. distribution}

In the Maxent model, the probability of a species to be present in an area is determined by a value in the range of $0-\mathrm{I}$. As the values approach I, the probability of the species to be present in that area potentially increases. For this reason, in this study, as the economic value of $P$. pinea $L$. is high, and it is frequently preferred in afforestation, the areas where the presence potential of the species was higher than 0.5 were considered in determining the current and potential distribution for the species. Afforestation activities are ecologically and economically risky investments, and the most important way of reducing investment risk is determination of the areas where the species could be potentially found to the highest degree. Therefore, for afforestation investments those are to be made especially for purposes of rural development, including the areas that are designated with the color red in Figure 4 in planning processes as a priority will increase the ecological success of afforestation activities, and therefore, their economic success (Carvalho et al., 2017).

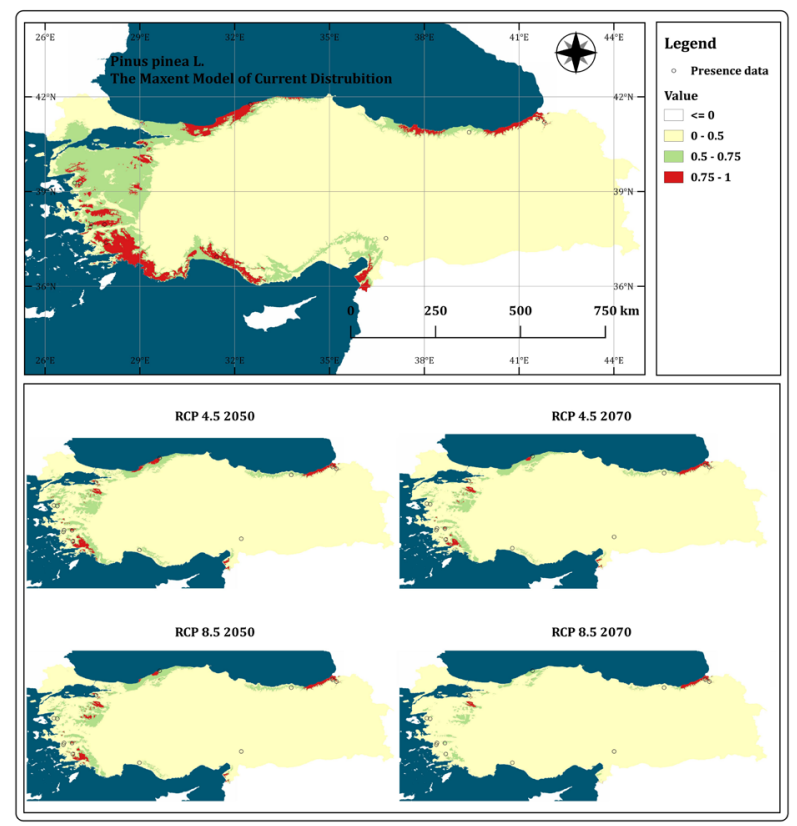

FIGURE 4 Pinus pinea L. bioclimatic habitat suitability maps in Turkey (Current, HadGEM2-ES RCP 4.5-8.5 2050, HadGEM2-ES RCP 4.5-8.5 2070). (0-0.5 unsuitable habitat, $0.5-0.75$ suitable habitat, $0.75-1$ higly suitable habitat).

Figure 4 shows the estimations on the predicted current and future potential distribution of $P$. pinea $\mathrm{L}$. reflected by the Maxent model by using QGIS version 3.6.2. Based on the data in the model, the potential distribution of $P$. pinea L. in the years 2050 and 2070 will decrease under the RCP 4.5 and RCP 8.5 climate change scenarios. Table 3 shows the amounts and ratios of the future habitat losses of $P$. pinea $\mathrm{L}$. According to Table 3, the suitable habitat conditions which are 125427 $\mathrm{km}^{2}$ today are estimated to be $55331 \mathrm{~km}^{2}$ (RCP 4.5) and $47726 \mathrm{~km}^{2}$ (RCP 8.5) for the year 2050. These values were estimated for the year 2070 as respectively 40037 $\mathrm{km}^{2}$ and $17793 \mathrm{~km}^{2}$. These data show that in the years 2050 and 2070 and in both scenarios, the suitable habitat areas of $P$. pinea $L$. will decrease. 
TABLE 3 Predicted current and future potential $P$. pinea $L$. habitat distributions.

\begin{tabular}{ccc}
\hline Pinus pinea L. & $\begin{array}{c}\text { Distribution } \\
\left(\mathrm{km}^{2}\right)\end{array}$ & $\begin{array}{c}\text { The ratio of the surface area of Turkey } \\
(\%)\end{array}$ \\
\hline Current & 125427 & 16.08 \\
RCP 4.5 2050 & 55331 & 7.09 \\
RCP 4.5 2070 & 40037 & 5.13 \\
RCP 8.5 2050 & 47726 & 6.12 \\
RCP 8.5 2070 & 17793 & 2.28 \\
\hline
\end{tabular}

\section{DISCUSSION}

Accordingly, the potential distribution of $P$. pinea $\mathrm{L}$. in the years 2050 and 2070 will decrease under the RCP 4.5 and RCP 8.5 scenarios. These estimates show that the geographical distribution of $P$. pinea $L$. will decrease in the future, and in both climate scenarios, the potential losses of habitat may reach significant levels. While climate change and increased land usage have been defined as the main reasons of habitat loss (Khanum et al., 20I3; Kumar, 20I2; Newbold et al., 20I5), habitat losses and fragmentations are seen as some of the most important factors in loss of biological diversity (Jiao et al., 2016; Linshan et al., 2017).

While the current ratio of the geographical distribution of $P$. pinea $L$. to the geographical area of Turkey is $16.08 \%$, it is expected to be $2.28 \%$ in the year 2070 under the RCP 8.5 scenario (Table 3). This indicates that the habitat losses of $P$. pinea $L$. in the future may reach a serious extent in the future based on climatic change. In contrast, some studies have found that the geographical distributions of some plant and insect species will increase based on climate change (West et al., 2015; Sarıkaya et al., 2018; Wei et al., 2018). It has also been projected that these species that are not invasive species today may turn into invasive species due to habitat losses and climatic change. For example, Leptoglossus occidentalis (Heidemann, 1910) (Heteroptera: Coreidae), which is a seed pest that used to not have a record in Turkey, was seen in recent years especially in the western regions of Turkey and recorded (Arslangündoğdu and Hizal, 2010). This demonstrates that climate change not only result in habitat losses, but they also affect many variables in the ecosystem. Other similar studies have supported this situation (Süel et al., 20 I8; Koç et al., 20I8; Mert and Kıraç, 2019).

Considering Figure 4, the current situation and future predictions together, it may be seen that the habitat losses of $P$. pinea $L$. were estimated to occur especially in the southern and western parts of Turkey. According to these results, climate change is shifting the distribution of $P$. pinea $L$. more towards the north and higher altitudes. Some other studies on the effects of climate change on plants reached similar results, and it was reported that especially plants distributed in the
Mediterranean region are under risk of extinction of they cannot adapt to climate change (Moiseev and Shiyatov, 2003; IPCC, 20I4; Khanum et al., 20I3; Mert et al., 2016; Dülgeroğlu and Aksoy, 20I8). However, it is also known that the endemic species in the Mediterranean region are more tolerant against the stress created by difficult habitat conditions, and they are affected less by natural and anthropogenic factors such as fire (Medail and Verlaque, 1997; Rundel et al., 20 I8; Dülgeroğlu and Aksoy, 2018). For this reason, it is important to take the appropriate precautions for future years and making plans by considering this issue in afforestation activities towards rural development in terms of the success of such afforestation activities and the continuity of the high added value provided by the species. But, According to a study in the Western Mediterranean, it is noteworthy that the society is not ready for the effects of climate change (Korkmaz, 2018).

\section{CONCLUSION}

P. pinea $\mathrm{L}$. is a species with high economic value that is frequently used in afforestation processes for various purposes. There is a need for further studies for investigating the geographical distribution of this species, which is used especially for rural development purposes, depending on forest ecosystem characteristics for the species to be able to sustain the ecological, economic and social benefits that are expected of it in the future. The results we obtained showed that $P$. pinea $L$. in Turkey will shift its geographical distribution in the future and experience losses of habitat. It is predicted that these habitat losses will occur especially in the western and southern part of Turkey. This situation has significance for protection and development of P. pinea L., which is a species with limited distribution. Therefore, the most suitable potential areas should be prioritized for afforestation activities to be carried out with this species in the present and the future. This also helps in conservation efforts (in situ or ex situ). Nevertheless, studies have demonstrated that changes in climate not only result in habitat losses, but they also negatively affect many variables in the ecosystem, change the biology and ecology of different species and lead to loss of biological diversity. This issue necessitates carrying out more detailed and comprehensive studies on climate change and interactions of species by integrating the topic of climate change into planning processes in ecosystems where biological diversity is high like especially forest ecosystems and protected areas. Hence, it will be possible to protect and sustain the ecological, economic 
and social benefits obtained from various species, especially regarding protection of biological diversity.

\section{REFERENCES}

ALLISON, I.; BINDOFF, N. L.; BINDSCHADLER, R. A.; COX, P. M.; DE NOBLET, N.; ENGLAND, M. H.; FRANCIS, J. E.; GRUBER, N.; HAYWOOD, A. M.; KAROLY, D. J.; KASER, G.; LE QUERE, C.; LENTON, T. M.; MANN, M. E.; MCNEIL, B. I.; PITMAN, A. J.; RAHMSTORF, S.; RIGNOT, E.; SCHELLNHUBER, H. J.; SCHNEIDER, S. H.; SHERWOOD, S. C.; SOMERVILLE, R. C. J.; STEFFEN, K.; STEIG, E. J.; VISBECK, M.; WEAVER, A. J. The Copenhagen Diagnosis: Updating the World on the Latest Climate Science, 2nd ed. Elsevier: Oxford, UK. 20I I. II4p.

ARSLANGÜNDOĞDU, Z.; HiZAL, E. The Western Conifer Seed Bug, Leptoglossus occidentalis (Heidemann, 1910), recorded in Turkey (Heteroptera: Coreidae). Zoology in The Middle East, v.50, n. I, p. 138-139, 2010.

BATUR, M. Relationships between pine nut Production, increment and some of meteorological data in Stone pine (Pinus pinea L.) forest of Kozak Region. Journal of Forestry Research, v. I, n. 2, p. 29-34, 2015.

BRAVO-OVIEDO, A.; MONTERO, G. Site index in relation to edaphic variables in stone pine (Pinus pinea L.) stands in south west Spain. Annals of Forest Science, v. 62, p. 6I-72, 2005.

CARVALHO, M. C.; GOMIDE, L.R.; SANTOS, R. M.; SCOLFORO, J. R. S.; CARVALHO, L. M. T.; MELLO, J.M. Modeling ecological niche of tree species in Brazilian tropical area. CERNE, v. 23, n. 2, p. 229-240, 2017.

CASTILLO, J. M.; CASAL, A. E. R.; LUQUE, C. J.; LUQUE, T.; FigUEROA, M. E. Comparative field summer stress of three tree species co-occuring Mediterranean coastal dunes. Phtosynthetica, v. 40, n. I, p. 49-56, 2002.

COUMOU, D.; RAHMSTORF, S. A decade of weather extremes. Nature Climate Change, v. 2. p. 49I-496, 2012 .

DAVIS, P.H. Flora of Turkey and the Aegean Islands. Vol.:IIX, Edinburgh University Press, London. 1982.

DAVIS, P.H.; TAN, K.; MILL, R. Flora of Turkey and tha Aegean Islands. Vol. $X$ (supplement), Edinburgh University Press, London. 1988.

DÜLGEROĞLU, C.; AKSOY, A. Predicting impacts of climate change on geographic distribution of Origanum minutiflorum Schwarz \& P.H. Davis using maximum entropy algorithm. Erzincan University Journal of Science and Technology, v. II, n. 2, p. I82-190, 2018.

ELITH, J.; PHILLIPS, S.J.; HASTIE, T.; DUDÍK, M.; CHEE, Y.E.; YATES, C.J. A statistical explanation of MaxEnt for ecologists. Diversity and Distributions, v. I7, n. I, p. 4357,2011 .
EUROPEAN NETWORK FOR EARTH SYSTEM MODELLING (ENES). Available at: https://portal.enes.org/models/ earthsystem-models/metoffice-hadley-centre/hadgem2-es. Accessed in February 10th 2019.

EUROPEAN FOREST GENETIC RESOURCES PROGRAMME (EUFORGEN). Available at: http://www.euforgen.org. Accessed in February 10th 2019.

FALCUCCI, A.; MAIORANO, L.; BOITANI, L. Changes in landuse/land-cover patterns in Italy and their implications for biodiversity conservation. Landscape ecology, v. 22, n. 4 , p. 6|7-63|, 2007.

FIELDING, A.H.; BELL, J.F. A review of methods for the assessment of prediction errors in conservation presence/ absence models. Environmental Conservation, v.24, p. 38-49, 1997.

FRANKLIN, J. Species distribution models in conservation biogeography: developments and challenges. Diversity and Distributions, v. 19, n. 10, p. 1217-1223, 2013.

GASSÓ, N.; THUILLER, W.; PINO, J.; VILÀ, M. Potential distribution range of invasive plant species in Spain. NeoBiota, v. I2, p. 25-40, 2012.

GLOBAL BIODIVERSITY INFORMATION FACILITY (GBIF). Available at: www.gbif.org. Accessed in February 10th 2019.

GUISAN, A.; THUILLER, W. Predicting species distribution: offering more than simple habitat models. Ecology Letters, v. 8, n. 9, p. 993-1009, 2005.

GÜLEÇ, A. The contribution of Pinus pinea forests to village legal entities and local economy: the case of Gediz Basin. I43 p. M.Sc. thesis Suleyman Demirel University, Isparta, 2015.

HIJMANS, R.J.; CAMERON, S.E.; PARRA, J.L.; JONES, P.G.; JARVIS, A. Very high resolution interpolated climate surfaces for global land areas. International Journal of Climatology, v. 25, p. 1965-1978, 2005.

HUGHES, L. Biological consequences of global warming: is the signal already apparent?. Trends in Ecology \& Evolution, v. $\mid 5$, n. 2, p. 56-6I, 2000.

IPCC. Climate change 2014: Synthesis report. Fifth Assessment Report of the Intergovernmental Panel on Climate Change. In: PACHAURI, R. K.; MEYER, L. A. Geneva, Switzerland, I5Ip, 2014

JIAO, S.; ZENG, Q.; SUN, G.; GUANGCHUN, L. Improving conservation of cranes by modeling potential wintering distributions in china. Journal of Resources and Ecology, v. 7, n. I, p. 44-50, 2016.

KESKIN, T.; MAKINECI, E. Some forest floor and soil properties of umbrella pine (Pinus pinea L.) and black locust (Robinia pseudoacacia L.) plantations on mine lands in Agaclı-Istanbul. Suleyman Demirel University Faculty of Forestry Journal, v. I, p. 38-5 I, 2009. 
KHANUM R.; MUMTAZ A.S.; KUMAR, S. Predicting impacts of climate change on medicinal asclepiads of Pakistan using Maxent modeling. Acta Oecologica-International Journal of Ecology, v. 49, p. 23-31, 2013.

KILCI, M.; SAYMAN, M.; AKBIN, G. Factors affecting the development of Stone Pine (Pinus pinea L.) in Western Anatolia, İzmir Forest Soil Laboratory publications, İzmir, Turkey, 2000. 130p.

KIRDAR, E.; ÖZEL, H.B.; ERTEKIN, M. Effects of pruning on height and diameter growth at stone pine (Pinus pinea $\mathrm{L}$.) Afforestations. Journal of Bartın Faculty of Forestry, v. 12, n. 18, p. I-10, 2010

KOÇ, D.E.; SVENNING, J.C.; AVCI, M. Climate change impacts on the potential distribution of Taxus baccata $\mathrm{L}$. in the Eastern Mediterranean and the Bolkar Mountains (Turkey) from last glacial maximum to the future. Eurasian Journal of Forest Science, v. 6, n. 3, p 69-82, 2018.

KORKMAZ, M. Public awareness and perceptions of climate change: Differences in concern about climate change in the West Mediterranean region of Turkey. Applied Ecology and Environmental Research, v. I6, n. 4, p. 4039-4050, 2018.

KUMAR, P. Assessment of impact of climate change on Rhododendrons in Sikkim Himalayas using Maxent modelling: limitations and challenges. Biodiversity and Conservation, v. 2I, p. 125I-1266, 2012.

KURT, R.; KARAYILMAZLAR, S.; IMREN, E.; CABUK, Y. Nonwood forest products in Turkey forestry sector: Export analysis. Journal of Bartın Faculty of Forestry, v. I8, n. 2, p. I58-167, 2016.

LAWLER, J.J.; SHAFER, S.L.; WHITE, D.; KAREIVA, P.; MAURER, E.P.; BLAUSTEIN, A.R.; BARTLEIN, P.J. Projected climate-induced faunal change in the Western Hemisphere. Ecology, v. 90, n. 3, p. 588-597, 2009.

LINSHAN, L.; ZHILONG, Z.; YILI, Z.; XUE, W. Using maxent model to predict suitable habitat changes for key protected species in Koshi Basin, Central Himalayas. Journal of Resources and Ecology, v. 8, n. I, p. 77-87, 2017.

MCLACHLAN, J.S.; CLARK, J.S.; MANOS, P.S. Molecular indicators of tree migration capacity under rapid climate change. Ecology, v. 86, n. 8, p. 2088-2098, 2005.

MEDAIL, F; VERLAQUE, R. Ecological characteristics and rarity of endemic plants from southeast France and Corsica: Implications for biodiversity conservation. Biological Conservation, v. 80, n. 3, p. 269-28I, 1997.

MERT, A.; KIRAÇ, A. Will Danford's Lizard become extinct in the future? Polish Journal of Environmental Studies, v. 28 , n. 3, p. $|74|-\mid 748,2019$.

MERT, A.; ÖZKAN, K.; ŞENTÜRK, Ö.; NEGIZ, M.G. Changing the potential distribution of Turkey Oak (Quercus cerris L.) under climate change in Turkey. Polish Journal of Environmental Studies., v. 25, n. 4, p. 1633-1638, 2016.
MOISEEV, P.A.; SHIYATOV, S.G. The use of old landscape photographs for studying vegetation dynamics at the tree line ecotone in the Ural Highlands, Russia. In: NAGY, L. Alpine Biodiversity in Europe. Springer-Verlag, Berlin, p.423-436, 2003.

MORENO-FERNÁNDEZ, D.; CAÑELLAS, I.; CALAMA, R.; GORDO, J.; SÁNCHEZ-GONZÁLEZ, M. Thinning increases cone production of stone pine (Pinus pinea L.) stands in the Northern Plateau (Spain). Annals of Forest Science, v. 70, p. 76I-768, 2013.

MOSS, R.H.; BABIKER, M.; BRINKMAN, S.; CALVO, E.; CARTER, T.; EDMONDS, J.A.; ZUREK, M. Towards new scenarios for analysis of emissions, climate change, Impacts, and response strategies. United States, IPCC Expert Meeting Report. Intergovernmental Panel on Climate Change, Geneva, Switzerland, 2008. 34p.

MUTKE, S.; GORDO, J.; GIL, L. Variability of Mediterranean Stone pine cone production: Yield loss as response to climate change. Agricultural and Forest Meteorology, v. I32, p. 263-272, 2005

NEWBOLD, T.; HUDSON, L.N.; HILL, S.L.L.; CONTU, S.; LYSENKO, I.; SENIOR, R.A.; et al. Global effects of land use on local terrestrial biodiversity. Nature, v. 520 , p. $45-$ 69, 2015.

ORMAN GENEL MÜDÜRLÜĞÜ (OGM). Action plan of Stone Pine (2006-2010), General Directorate of Forestry, Ankara, Turkey, 24p., 2006.

ORMAN GENEL MÜDÜRLÜĞÜ (OGM). General Directorate of Forestry. Avaiable at: www.ogm.gov.tr. Accessed in November 15th 2018.

OLIVEIRA, M.D.; HAMILTON, S.K.; CALHEIROS, D.F.;JACOBI, C.M.; LATINI, R.O. Modeling the potential distribution of the invasive golden mussel Limnoperna fortunei in the upper Paraguay river system using limnological variables. Brazilian Journal of Biology, v. 70, n. 3, p. 83I-840, 2010.

PARMESAN, C. Ecological and evolutionary responses to recent climate change. Annual Review of Ecology, Evolution, and Systematics., v. 37, p. 637-669, 2006.

PHILLIPS, S.J. A brief tutorial on Maxent. Lessons in Conservation, v. 3, p. 107-135, 2010.

PHILLIPS, S.J.; ANDERSON, R.P.; DUDÍK, M.; SCHAPIRE, R.E.; BLAIR, M.E. Opening the black box: An open-source release of Maxent. Ecography, v. 40, p. 887-893, 2017.

PHILLIPS, S.J.; ANDERSON, R.P.; SCHAPIRE, R.E. Maximum entropy modeling of species geographic distributions. Ecological Modelling, v. 190, p. 231-259, 2006.

PHILLIPS, S.J.; DUDÍK, M. Modeling of species distributions with Maxent: new extensions and a comprehensive evaluation. Ecography, v. 3I, n. 2, p. I6I-I75, 2008. 
ROOT, T.L.; SCHNEIDER, S.H. Conservation and climate change: the challenges ahead. Conservation Biology, v. 20, n. 3, p. 706-708, 2006.

RUNDEL, P.W.; ARROYO, M.T.K.; COWLING, R.M.; KEELEY, J.E.; LAMONT, B.B.; PAUSAS, J.G.; VARGAS, P. Fire and plant diversification in Mediterranean-climate regions. Frontiers in Plant Science, v. 9, p. 1-13, 2018.

SARIKAYA, O.; KARACEYLAN, I.B.; ŞEN, İ. Maximum entropy modeling (maxent) of current and future distributions of Ips mannsfeldi (Wachtl, 1879) (Curculionidae: Scolytinae) in Turkey. Applied Ecology and Environmental Research, v. I6, n. 3, p. 2527-2535, 2018.

SCHIVO, F; BAUNI, V.; KRUG, P.; QUINTANA, R.D. Distribution and richness of amphibians under different climate change scenarios in a subtropical region of South America. Applied Geography, v. 103, p. 70-89, 2019.

SHARMA, S.; ARUNACHALAM, K.; BHAVSAR, D.; KALA, R. Modeling habitat suitability of Perilla frutescens with MaxEnt in Uttarakhand-A conservation approach. Journal of Applied Research on Medicinal and Aromatic Plants, v. 10, p. 99-105, 2018.

SISCO, M.R.; BOSETTI, V.; WEBER, E.U. When do extreme weather events generate attention to climate change? Climatic Change, v. 143, p. 227-24I, 2017.

SÜEL, H.; MERT, A.; YALÇINKAYA, B. Changing potential distribution of gray wolf under climate change in Lake District, Turkey. Applied Ecology and Environmental Research, v. 16, n. 5, p. 7129-7/37, 2018.

ŞAFAK, I.; OKAN, T. Production and marketing of thyme, laurel and pine nuts, Aegean Forestry Research Directorate, İzmir, Turkey, 2004, I29p.

ŞENSOY, H.; ATEŞOĞLU, A. A review of climate type variability from Bartın Region. Journal of Bartin Faculty of Forestry, v. 20, n. 3, p. 576-582, 2019.

TEOBALDELLI, M.; MENCUCCINI, M.; PIUSSI, P. Water table salinity, rainfall and water use by umbrella pine trees (Pinus pinea L.). Plant Ecology, v. I7I, p. 23-33, 2004.
TICKTIN, T. The ecological implications of harvesting nontimber forest products. Journal of Applied Ecology, v. 4I, n. I, p. II-2I, 2004.

ÜÇLER, A.Ö.; ARPACI, M. Correlations between some physiographic factors and diameter, height and cone characteristics in stone pine (Pinus pinea L.) afforestation areas in Balıkesir-Burhaniye Region. Artvin Coruh University Journal of Forestry Faculty, v. 18, n. 2, p.218-227, 2017.

WEI, B.; WANG, R.; HOU, K.; WANG, X.; WU, W. Predicting the current and future cultivation regions of Carthamus tinctorius L. using MaxEnt model under climate change in China. Global Ecology and Conservation, v. I6, p. I-12, 2018.

WEST, A.M.; KUMAR, S.; WAKIE, T.; BROWN, C.S.; STOHLGREN, T.j.; LAITURI, M.; BROMBERG, J. Using High-resolution future climate scenarios to forecast Bromus tectorum invasion in Rocky Mountain National Park. PLoS ONE, v. I0, n. 2, p. I-I5, 2015.

WORLDCLIM, 2019. WorldClim - Global Climate Data. Avaiable at: www.worldclim.org. Accessed in February IOth 2018.

YALTIRIK, F. Gymnospermae (Açık Tohumlular). Istanbul University publishing, İstanbul, Turkey, 1988. 320p.

YILMAZ, M.; ERBiLGIN, N. Fıstıkçamı (Pinus pinea L.)'nın yangına ve böceklere karşı dayanıklılığı. Journal of the Chamber of Forest Engineers, v. 47, n. 3, p. I8-2I, 2010.

ZANK, C.; BECKER, F.G.; ABADIE, M.; BALDO, D.; MANEYRO, R.; BORGES-MARTINS, M. Climate change and the distribution of neotropical red-bellied toads (Melanophryniscus, Anura, Amphibia): how to prioritize species and populations?. PLoS One, v. 9, n. 4, p. I-II, 2014.

ZHANG, K.; ZHANG, Y.; ZHOU, C.; MENG, J.; SUN, J.; ZHOU, T.; TAO, J. Impact of climate factors on future distributions of Paeonia ostii across China estimated by MaxEnt. Ecological Informatics, v. 50, p. 62-67, 2019. 